\title{
Optimum Ratio of Fresh Manure and Grain Size of Phosphate Rock Mixture in a Formulated Compost for Organomineral NP Fertilizer
}

\author{
Sutopo Ghani Nugroho ${ }^{1}$, Dermiyati ${ }^{1}$, Jamalam Lumbanraja ${ }^{1}$, Sugeng Triyono ${ }^{2}$, Hanung Ismono ${ }^{3}$, \\ Yosa Triolanda Sari ${ }^{1}$, and Elva Ayuandari ${ }^{1}$ \\ ${ }^{1}$ Soil Science Division, ${ }^{2}$ Agricultural Engineering Department, and ${ }^{3}$ Agricultural Economics Department, \\ Faculty of Agriculture, University of Lampung, Jl. Sumantri Brojonegoro No.1, Bandarlampung, \\ Indonesia 35145, phone/fax:+62-721-781822, e-mail: sutopo@unila.ac.id
}

Received 12 December 2011 / accepted 2 May 2012

\begin{abstract}
The objective of multi years study was to formulate an alternative organic based fertilizer by mixing a fresh manure and phosphate rock with several different grain sizes conducted in the Field Experimental Station of the University of Lampung. Both materials of the fresh manure and phosphate rock were obtained from local sources. Five levels of mixture of fresh manure and phosphate rock, three levels of grain size of phosphate rock, and two kinds of composting technique were factorial set up. The mixture materials were aerobically composted for 12 weeks. The results of the first year study show that (a) the optimum ratio of the mixture of fresh manure and phosphate rock was $80 \%$ to $20 \%$ with the optimum of grain size of phosphate rock $<3 \mathrm{~mm}$; (b) $6-8$ weeks of incubation of the mixture materials has been optimally composted under aerobic conditions of the complete mixture of batch composted technique; (c) the quality of the final produced compost was considered to fulfill the requirement of standard criteria of organic fertilizer; while (d) the quantity of compost recovered up to $75.07 \%$ which was a reliable quantity of mass production of organic fertilizer.
\end{abstract}

Keywords: Composting, fresh manure, organic fertilizer, organonitrophos, rock phosphate

\section{INTRODUCTION}

Fertilizer is a major input in agricultural production in the tropics due to very low fertility level of humid tropical soils as well as commonly intensive practices of crop production. Currently, the price of chemical (inorganic) fertilizer in Indonesia is continously increasing due to the increasing of fossil energy price as well as the other imported raw materials needed for the production of inorganic fertilizer. The high price of inorganic fertilizers will not be afforded by the farmers unless it is subsidized by the government. However, the government budget for subsidized fertilizer will be continously soaring which will not be affordable. Data shows that in 2004 the government budget for fertilizer subsidy was amounted only Rp1,171,4 billion which was soaring to the amount of Rp17.537,0 billion in 2009 (Kamenko Perekonomian RI 2009).

In the intensive agricultural practices, farmers become very dependent on inorganic fertilizers and

J Trop Soils, Vol. 17, No. 2, 2012: 121-128 ISSN 0852-257X have a tendency of ignoring the use of organic matter which actually can maintain quality of soils and, therefore, can sustain agricultural production (Rodriquez and Fraga 1999). Consequently, organic matter level in soils will continously decrease to the level that the quality of soil will not be able to support a sustainable crop production. The quality of soil is also essentially determined by organic matter content since it significantly influences the physical, chemical, and biological properties of soil. Actually, the application of organic materials to the soil either in the form of raw materials or in the form of compost has been practically applied for long time in the agricultural history.

Lately, the Government of Indonesia has taken a promising policy to promote the use of organic fertilizers in the agricultural practices so called go organic by developing, manufacturing and distributing the organic fertilizers. Furthermore, the government policy to include the organic fertilizers as a part of government's subsidized fertilizers.

Generally, farmers are using the subsidized inorganic fertilizers having high contents of $\mathrm{N}$ (such 
as Urea) and P (such as TSP or SP-36), while the subsidized organic fertilizers have normally very low content of $\mathrm{N}$ and $\mathrm{P}$. To match the farmer needs of substitution a part of the inorganic fertilizers, therefore, there will be nessasary to develop organic fertilizers that can supply adequate contents both $\mathrm{N}$ and $\mathrm{P}$ nutrients. Especially, such organic fertilizers can be developed from raw materials potentially available from local sources, such as fresh manure and phosphate rock. In Lampung, the fresh manure from several feedlots as much as $576.700 \mathrm{Mg}$ was produced annually; similarly the phosphate rocks are available in a huge deposit in the west part of Central Lampung.

Fresh organic matter of fresh manure can be decomposed by microbes to produce several organic compounds, compost and to mineralize organic $\mathrm{N}$ to form inorganic $\mathrm{N}\left(\mathrm{NH}_{4}^{+}-\mathrm{N}\right.$ and $\left.\mathrm{NO}_{3}-\mathrm{N}\right)$ that can be available for crops (Hidersah and Simarmata 2004). During the decomposition process of the fresh manure, the growth of certain microbes such as $\mathrm{N}$-fixers and $\mathrm{P}$-solubilizers will be promoted (Gupta et al. 1994). The growing population of Nfixers will eventually help to increase the $\mathrm{N}$ content of the composted materials by fixing atmospheric $\mathrm{N}_{2}$.

The phosphate rocks are naturally able to release phosphates ions $\left(\mathrm{H}_{2} \mathrm{PO}_{4}{ }^{1-}, \mathrm{HPO}_{4}{ }^{2-}\right)$ being available for crops. However, the released ions are normally very slow and very low in availability (Ilmer and Schiner 1995). The released phosphate ions can be increased when $\mathrm{H}^{+}$concentration is high (acids condition) such as in acid soils (Traina et al. 1986), in the rhizosphere where P-solubilizers grow (Reyes et al. 2002; Sabaruddin et al. 2011), or in phosphate fertilizer industry by adding strong acid (Priyambada, et al. 2009). The growing population of $\mathrm{P}$-solubilizers will act synergistically with the $\mathrm{H}^{+}$of organic acids produced during the decomposition process to solubilize the phosphate rock (Alam et al. 2002; Asea et al. 1988; Siddique and Robinson. 2003; Soelaeman 2008; Noor 2008; Kumari et al. 2008; Taiwo and Ogundiya 2008) when organic materials (such as fresh manure) is mixed with rock phosphate.

Conceptually, if the mixture of the fresh manure and phosphate rock has been designed accurately from the beginning of composting process, such as the ratio of the mixture of fresh manure and the phosphate rock is proper, the grain size of phosphate rock is ideal, the composting technique is proper, and the length of incubation is enough under controlled composting process, it can be found the optimum ratio of the mixture of fresh manure and rock phosphate with proper grain size. The optimum ratio can be called as prospective formula of prototype of alternative organomineral NP (organonitrophos) fertilizer which contains of a signicantly high enough of available $\mathrm{N}$ and $\mathrm{P}$ nutrients.

The objective of the study was to formulate an alternative organic matter based-fertilizers derived from the mixture of fresh manure (from feedlot) and phosphate rock so that the fertilizer has a capacity to supply enough available $\mathrm{N}$ and $\mathrm{P}$ through a process of controlled aerobic composting technique. In addition, the mixture material was innoculated by decomposers, N-fixers, and Psolubilizers.

The outcome of the study is a new designed of the alternative organomineral NP (organonitrophos) fertilizer that has been tested accurately in the laboratory, green house, and in the field. The raw materials are available locally, therefore, this alternative fertilizer can be mass produced at low cost.

\section{MATERIALS AND METHODS}

\section{Materials}

Materials for formulating the organomineral NP (organonitrophos) fertilizer were obtained from local sources. Fresh cattle manure (FM) was obtained from the cattle feedlot industry of PT Juang Jaya Abdi Alam, Kota Dalam, Sidomulyo, South Lampung; while phosphate rock (PR) was obtained from the community mining located at Sidoharjo, Selagai Lingga, Central Lampung. The fresh manure was characterized by high water content (61.32\%), high $\mathrm{pH}$ (8.21), medium content of organic-C (22.85\%), low content of organic-N (1.08\%), very low content of total-P $\left(0.31 \% \mathrm{P}_{2} \mathrm{O}_{5}\right)$, and very low content of soluble-P $\left(0.15 \% \mathrm{P}_{2} \mathrm{O}_{5}\right)$. The phosphate rock was characterized by neutral $\mathrm{pH}$ (7.86), medium content of total-P $\left(25.60 \% \mathrm{P}_{2} \mathrm{O}_{5}\right)$, and low content of soluble-P $\left(5.20 \% \mathrm{P}_{2} \mathrm{O}_{5}\right)$. The phosphate rock was exposed to air dry and then grained into three size grain groups that were $<1.0 \mathrm{~mm},<3.0$ $\mathrm{mm}$, and $<5.0 \mathrm{~mm}$.

\section{Experiment Outline}

The current experiment consisted of two sub Experiments. Sub-experiment I was to determine the optimum ratio of a mixture of FM and varying grain size of PR. The sub-experiment II was to elaborate the proper design composting technique 
between complete mixture- and pile mixturetechniques.

The current design ratio of the mixture of FM and PR with different grain size was based on the result of the earlier pot experiment. The result indicated that the ratio $80: 20$ was reasonable accepted meaning that the $80 \%$ of FM and $20 \%$ of $\mathrm{RP}$ with grain size either $<1 \mathrm{~mm}$ or $<3 \mathrm{~mm}$ was the optimum ratio of the mixture which released the highest amount of the mineral- $\mathrm{N}\left(\mathrm{NH}_{4}-\mathrm{N}\right.$ and $\mathrm{NO}_{3}-$ $\mathrm{N})$ and the soluble-P after the mixture was composted at least for two months. The current design ratio of the mixture was to determine a more precise optimum ratio, which consisted of $90 \mathrm{FM}$ : 10 RP, 85 FM : 15 RP, 80 FM : 20 RP, 75 FM : 25 RP, and $70 \mathrm{FM}: 30 \mathrm{RP}$. The current grain size of RP used was similar as used in the earlier pot experiment conducted, which consisted of $<1 \mathrm{~mm}$, $<3 \mathrm{~mm}$, and $<5 \mathrm{~mm}$. Therefore, the treatment design $5 \times 3$ factorial was applied in the sub-experiment I; while in the sub-experiment II, two kind treatments of composting technique which consisted of complete mixture- and pile mixture-technique were applied. The overall treatment combination, a $5 \times 3$ $\times 2$ experimental units with 3 replications, was setup.

\section{Composting Techniques and Equipments}

The composting technique used was a simple batch system that was in a static pile, where the mixture material was merely stacked meaning that was not mechanically turned or inverted (Misra et al. 2003). Wooden constructed box with size of 120 $\times 80 \times 50 \mathrm{~cm}$ was used for placing the mixture of FM and PR to be composted. The box capacity volume was designed to load the mixture amounted up to $400 \mathrm{~kg}$. The loading was filled up portion by portion (layer by layer) which each box was divided into four layers (portions). For weighing the portion of FM- or PR- material of each design treatment, the FM- or PR-material was weighed proportionally and appropriately to the ratio designed on the basis of the total weight of $400 \mathrm{~kg}$; e.g. for the treatment ratio of $90 \mathrm{FM}$ : $10 \mathrm{PR}$, the amount of $360 \mathrm{~kg}$ FM and $40 \mathrm{~kg}$ PR of each grain size were respectively weighed.

Transferring the mixture of FM and PR into the box was also filled up layer by layer (portion by portion) which each layer of each box has to be loaded with $100 \mathrm{~kg}$ of the mixture. At first, the FM material as much as the portion according to the treatment ratio was transferred into the box, then the following was the portion of PR material was added. For the treatment of complete mixture- technique, the two materials were thoroughly mixed, while for the treatment of pile mixture-technique, the PR material was poured as a layer over the FM material layer. Similar procedure was continuously done to transfer the rest of mixture material up to the weight amounted to $400 \mathrm{~kg}$ of each box. For each layer, the decomposer $(500 \mathrm{ml}$ dilluted in 450 $\mathrm{ml}$ water) was poured completely either in the pilemix tube or the complete-mixture composting technique. All the boxes containing the mixture material were covered with polyethylene plastic and then were placed randomly in composting house during twelve weeks of incubation period.

For the purpose of supplying $\mathrm{O}_{2}$ for maintaining aerobic conditions inside the composting box, an aerator system consisted of pipe lines and automatic compressor was set-up. The compressor used can regularly supply air at 3 atm to keep the $\mathrm{O}_{2}$ diffusion in to the pile. The water content of mixture material was maintained at level $50-60 \%$ during the incubation period.

\section{Samplings and Measurements}

Samplings of compost material were taken periodically at the beginning of day 1 , two weeks, four weeks, six weeks, eight weeks, ten weeks, and twelve weeks after incubation during the incubation period. One meter length of galvanized auger sampler was used to take the mixture material randomly from 5 points of each box. The collected materials from 5 points of each box were then mixed thoroughly to be one composite sample. The composite samples of all experiment units were kept in refrigerator at $18^{\circ} \mathrm{C}$ before the analysis of chemical variables of the compost materials were done.

The measurements were made on the water content (gravimetric), $\mathrm{pH}$ (electrometric), organic$\mathrm{C}$ (Walkley and Black), organic-N (Kjeldahl), mineral-N: $\mathrm{NH}_{4}-\mathrm{N}$ (Indophenol Blue) and $\mathrm{NO}_{3}-\mathrm{N}$ (Hydrazine Reduction), total-P ( $\mathrm{HCl} 25 \%)$ and soluble-P (citric-acid 2\%). Measurement of all treatment samples of one replication were conducted in one day.

Incubation of the composting process was completed for twelve weeks. The finished compost was harvested by weighing fresh weight, air drying up to $25 \%$ of water content, grinding and screening, weighing dry weight and finally packaging.

\section{Statistical Analysis}

Each chemical variable of composted material was averaged over three replication values. Analisys of variance was performed to test the effects of 
treatment of the mixture of FM and RP with varying grain size on several key chemical variables such as $\mathrm{pH}$, organic- $\mathrm{C}$, organic- $\mathrm{N}$, inorganic- $\mathrm{N}\left(\mathrm{NH}_{4}-\mathrm{N}\right.$ and $\mathrm{NO}_{3}-\mathrm{N}$ ), as well as total-P and soluble-P. Finally, the optimum ratio of the mixture of fresh manure and rock phosphate with varying grain size obtained was recommended as the prospective formula of the prototype of organomineral NP (organonitrophos) fertilizer.

\section{RESULTS AND DISCUSSION}

\section{Compost Maturity}

The compost maturity of the mixture of fresh manure and phosphate rock with varying grain size was tested by determining the ratio of $\mathrm{C}$ to $\mathrm{N}(\mathrm{C} / \mathrm{N}$ ratio) of the mixture treatments which were periodically measured at every two weeks during the incubation period. Figure 1 and Figure 2 show the $\mathrm{C} / \mathrm{N}$ ratio evolution of the mixture in the complete mixture- and pile mixture-composting technique, respectively.

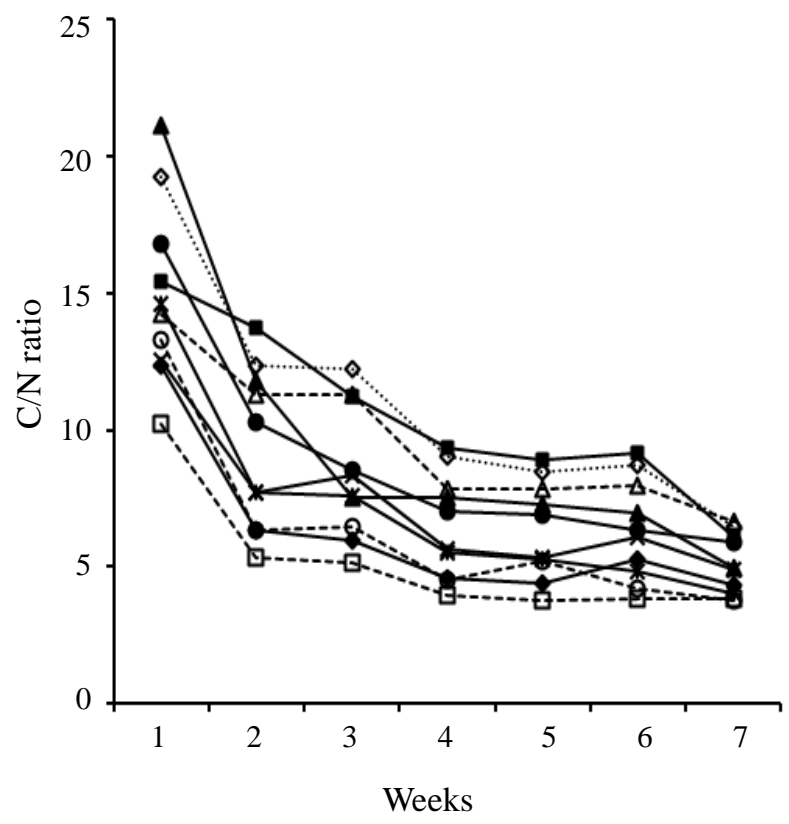

Figure 1. The $\mathrm{C} / \mathrm{N}$ Ratio evolution of the mixture in the complete-mixture composting technique. H10C $(\multimap-)=$ fine grain, $10 \%$ PR; H20C $(\rightarrow-)=$ fine grain, $20 \%$ PR, H30C $(\neg)=$ fine grain, $30 \%$ PR, K10C $(\rightarrow)=$ coarse grain, $10 \%$ PR, K20C $(\rightarrow-)=$ coarse grain, $20 \%$ PR, K30C $(\rightarrow-)=$ coarse grain, $30 \%$ PR, S10C $(--\square--)=$ medium size grain, $10 \%$ PR, S20C $(-----)=$ medium size grain, $20 \%$ PR, S30C $(--\Delta-\cdot)=$ medium size grain, $30 \%$ PR, and control $(\cdot \diamond \cdot \cdot)$.
From Figure 1 and Figure 2, it can be seen that either in complete mixture or pile mixture composting technique, the $\mathrm{C} / \mathrm{N}$ ratio of all the mixture treatments decreased rapidly during two weeks of incubation to reach the $\mathrm{C} / \mathrm{N}$ ratio value ranging from 5 to 10 , except for some mixture treatments with high portion of phosphate rock. The mixture of most the mixture treatments have matured after only two weeks of incubation. This because of the main component of the material mixture was the fresh (cattle) manure, which normally contains an appreciable amount of water soluble (simple component) of organic compounds such as amino acids, organic acids, and sugars that are readily available for fast decomposition by the microbes growing in the material mixture.

After two weeks of incubation, the $\mathrm{C} / \mathrm{N}$ ratio of all of the mixture treatments decreased only slightly and the value of $\mathrm{C} / \mathrm{N}$ ratio were almost stable since after six weeks of incubation. Based on the results of $\mathrm{C} / \mathrm{N}$ ratio evolution discussed above the length of six to eight weeks of incubation was considered as the optimum length of incubation period.

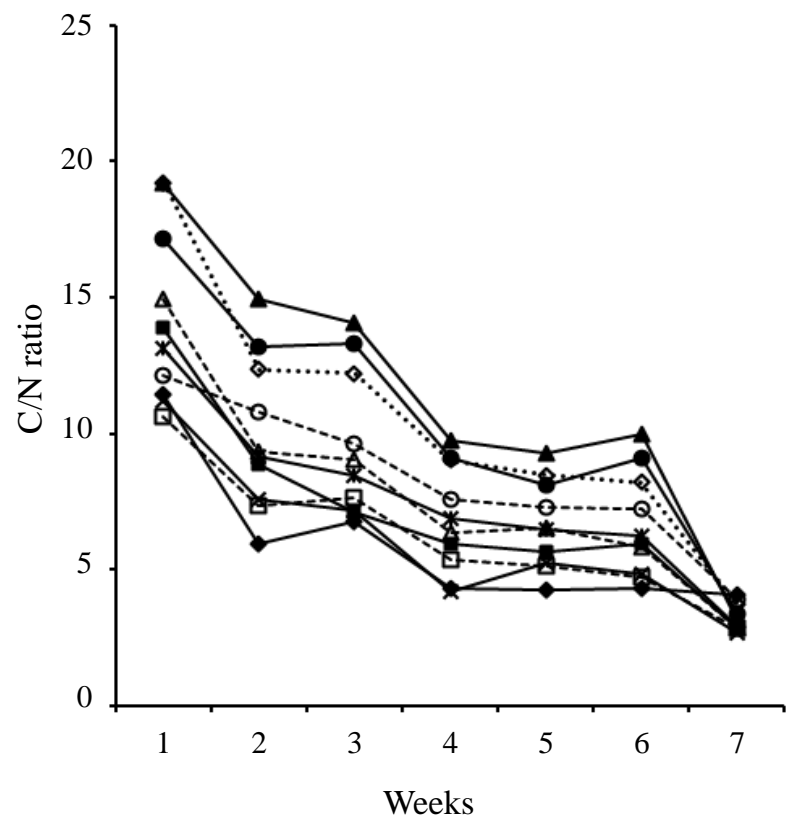

Figure 2. The $\mathrm{C} / \mathrm{N}$ Ratio evolution of the mixture in the pile-mixture composting technique. H10L $(\multimap-)=$ fine grain, $10 \%$ PR; H20L $(\rightarrow-)=$ fine grain, $20 \%$ PR, H30L $(\neg)=$ fine grain, $30 \%$ PR, $\mathrm{K} 10 \mathrm{~L}(\rightarrow)=$ coarse grain, $10 \% \mathrm{PR}$, K20L $(\rightarrow-)=$ coarse grain, $20 \%$ PR, K30L $(\rightarrow-)=$ coarse grain, $30 \%$ PR, S10L (-- --*) = medium size grain, $10 \%$ PR, S20L (-๑--) $=$ medium size grain, $20 \%$ PR, S30L (--A--) = medium size grain, 30\% PR, and control $(\cdot \bullet \cdot \cdot)$. 


\section{Quality of Compost}

The quality of final compost produced from the mixture of fresh manure and phosphate rock with different grain size was characterized using several criteria such as $\mathrm{pH}$, organic- $\mathrm{C}$, amount of organic$\mathrm{N}$ and its available form of inorganic- $\mathrm{N}\left(\mathrm{NH}_{4}-\mathrm{N}\right.$ and $\mathrm{NO}_{3}-\mathrm{N}$ ) as well as amount of total-P and its available form of soluble-P. Measurement data of the eight weeks incubation were used for the interpretation of the quality of final produced compost.

\section{Acidity (pH) and Organic-C}

There were combination effects of the mixture ratio of fresh manure and phosphate rock and the grain size of phosphate rock on $\mathrm{pH}$ and organic-C of the compost after eight weeks of incubation (Table 1).

The $\mathrm{pH}$ values of the mixture materials were not different among the mixture treatments which the values were slightly alkaline. This because of buffering effect was acted by Ca released from the phosphate rock materials. Data of the eight weeks of incubation show that the value of organic-C of most of the mixture treatments was also relatively even ranging from $12.81 \%$ to $14.58 \%$. This because of the appreciable amount of organic compounds of the mixture materials were already subjected to fast decomposition in early weeks of incubation.

\section{Organic- and Inorganic-N}

There were combination effects of the mixture ratio of fresh manure and phosphate rock and the grain size of phosphate rock on the organic- $\mathrm{N}$ and inorganic-N of the compost after eight weeks of incubation (Table 2). The organic-N of the compost product increased slightly from the ratio 90 (FM) : 10 (PR) to 80 (FM) : 20 (PR), especially with the medium grain size $(<3 \mathrm{~mm})$. This probably due to the addition of fixed-N contributed by the optimally growing population of the $\mathrm{N}$-fixers. It clear that in term of organic-N, under conditions of optimum ratio, the value reached $2.46 \%$. Accordingly, the inorganic-N reached the level up to $0.46 \%$ under the conditions of optimum ratio; in which the population of ammonifers optimally grew.

\section{Total- and Soluble-P}

The combination effects of the mixture ratio of fresh manure and rock phosphate and the grain

Table 1. Combination effect of the mixture ratio (fresh manure and phosphate rock) and the grain size of phosphate rock on the organic- $\mathrm{C}$ and $\mathrm{pH}$ of the final produced compost in the complete mixture composting technique.

\begin{tabular}{|c|c|c|c|c|c|c|}
\hline \multirow{3}{*}{$\begin{array}{c}\text { Mixture } \\
\text { Ratio of FM } \\
\text { and PR }\end{array}$} & \multicolumn{3}{|c|}{$\mathrm{pH}$} & \multicolumn{3}{|c|}{ Organic-C (\%) } \\
\hline & \multicolumn{3}{|c|}{ Grain size of phosphate rock } & \multicolumn{3}{|c|}{ Grain size of phosphate rock } \\
\hline & $<1 \mathrm{~mm}$ & $<3 \mathrm{~mm}$ & $<5 \mathrm{~mm}$ & $<1 \mathrm{~mm}$ & $<3 \mathrm{~mm}$ & $<5 \mathrm{~mm}$ \\
\hline $90: 10$ & 8.02 & 8.10 & 8.07 & 14.46 & 14.31 & 14.58 \\
\hline $85: 15$ & 8.07 & 8.06 & 8.09 & 14.26 & 13.67 & 14.26 \\
\hline $80: 20$ & 7.97 & 8.14 & 8.17 & 13.51 & 14.93 & 14.04 \\
\hline $75: 25$ & 8.15 & 8.06 & 8.01 & 13.54 & 13.70 & 13.67 \\
\hline $70: 30$ & 7.96 & 7.91 & 8.01 & 12.81 & 13.13 & 12.98 \\
\hline
\end{tabular}

Table 2. Combination effect of the mixture ratio (fresh manure and phosphate rock) and the grain size of phosphate rock on the organic- $\mathrm{N}$ and inorganic- $\mathrm{N}$ of the final produced compost in the complete mixture composting technique.

\begin{tabular}{|c|c|c|c|c|c|c|}
\hline \multirow{3}{*}{$\begin{array}{c}\text { Mixture } \\
\text { Ratio of FM } \\
\text { and PR }\end{array}$} & \multicolumn{3}{|c|}{ Organic-N (\%) } & \multicolumn{3}{|c|}{ Inorganic-N (\%) } \\
\hline & \multicolumn{3}{|c|}{ Grain size of phosphate rock } & \multicolumn{3}{|c|}{ Grain size of phosphate rock } \\
\hline & $<1 \mathrm{~mm}$ & $<3 \mathrm{~mm}$ & $<5 \mathrm{~mm}$ & $<1 \mathrm{~mm}$ & $<3 \mathrm{~mm}$ & $<5 \mathrm{~mm}$ \\
\hline $90: 10$ & 2.28 & 2.39 & 2.54 & 0.40 & 0.45 & 0.45 \\
\hline $85: 15$ & 2.44 & 2.35 & 2.28 & 0.40 & 0.36 & 0.46 \\
\hline $80: 20$ & 2.51 & 2.64 & 2.30 & 0.43 & 0.46 & 0.43 \\
\hline $75: 25$ & 1.88 & 2.13 & 2.15 & 0.26 & 0.32 & 0.29 \\
\hline $70: 30$ & 1.76 & 1.90 & 1.66 & 0.48 & 0.41 & 0.14 \\
\hline
\end{tabular}


Table 3. Combination effect of the mixture ratio (fresh manure and phosphate rock) and the grain size of phosphate rock on the total-P and soluble-P of the final produced compost in the complete mixture composting technique.

\begin{tabular}{|c|c|c|c|c|c|c|}
\hline \multirow{3}{*}{$\begin{array}{c}\text { Mixture } \\
\text { Ratio of FM } \\
\text { and PR }\end{array}$} & \multicolumn{3}{|c|}{ Total-P (\%) } & \multicolumn{3}{|c|}{ Soluble-P (\%) } \\
\hline & \multicolumn{3}{|c|}{ Grain size of phosphate rock } & \multicolumn{3}{|c|}{ Grain size of phosphate rock } \\
\hline & $<1 \mathrm{~mm}$ & $<3 \mathrm{~mm}$ & $<5 \mathrm{~mm}$ & $<1 \mathrm{~mm}$ & $<3 \mathrm{~mm}$ & $<5 \mathrm{~mm}$ \\
\hline $90: 10$ & 2.58 & 2.28 & 2.38 & 0.75 & 0.70 & 1.18 \\
\hline $85: 15$ & 3.41 & 3.16 & 3.14 & 1.41 & 1.32 & 1.20 \\
\hline $80: 20$ & 4.51 & 4.91 & 4.93 & 1.53 & 1.66 & 1.64 \\
\hline $75: 25$ & 5.35 & 5.40 & 5.66 & 1.72 & 1.77 & 1.78 \\
\hline $70: 30$ & 5.76 & 5.76 & 6.11 & 2.07 & 2.25 & 2.11 \\
\hline
\end{tabular}

Table 4. Combination effect of the mixture ratio (fresh manure and phosphate rock) and the grain size of phosphate rock on the quantity of harvested compost after twelve weeks in the complete mixture composting technique.

\begin{tabular}{cccc}
\hline \multirow{2}{*}{$\begin{array}{c}\text { Mixture Ratio of } \\
\text { FM and RP }\end{array}$} & \multicolumn{3}{c}{ Quantity of harvested compost $\left(\mathrm{kg} \mathrm{box}^{-1}\right)$} \\
\cline { 2 - 4 } & $<1 \mathrm{~mm}$ & \multicolumn{3}{c}{ Grain size of phosphate rock } \\
\hline $90: 10$ & 293.67 & 290.00 & $<5 \mathrm{~mm}$ \\
$85: 15$ & 265.67 & 288.67 & 269.00 \\
$80: 20$ & 300.30 & 300.33 & 278.33 \\
$75: 25$ & 256.33 & 287.00 & 296.00 \\
$70: 30$ & 300.10 & 298.05 & 293.33 \\
\hline
\end{tabular}

Note: Each composting box originally contains $400 \mathrm{~kg}$ of material mixture.

size of rock phosphate on the total-P and soluble-P of the final produced compost after eight weeks of incubation was not clearly observed (Table 3). Data of total-P and soluble-P in Table 3 show that the portion of phosphate rock significantly contributed to the level of total-P and soluble-P in the mixture materials which increasing the portion of phosphate rock followed by the increase of total-P as well as soluble-P for all of the grain size of phosphate rock. The combination treatment of $80 \%$ fresh manure and $20 \%$ of phosphate rock with medium grain size $<3 \mathrm{~mm}$ was considered appropriate to mutually affect the transformation of $\mathrm{P}$ in the compost materials.

\section{Quantity of Compost Harvested}

The quantity of compost harvested was measured at the time after twelve weeks of incubation. There were also combination effects of the mixture ratio of fresh manure and phosphate rock and the grain size of phosphate rock on the quantity of compost harvested (Table 4). It clear that the combination treatment of $80 \%$ fresh manure and $20 \%$ of phosphate rock with medium grain size $<3 \mathrm{~mm}$ yielded the highest amount of harvested compost recovered upto $75.07 \%$ from the quantity of initial materials.

\section{Optimum Ratio of Mixture and Prospective Prototype Formula}

Based on the value obtained from the selected criteria used which have been statistically tested for characterization of the mixture of the fresh manure and varying grain of the phosphate rock such as $\mathrm{C} / \mathrm{N}$ ratio, $\mathrm{pH}$, organic- $\mathrm{C}$, organic- $\mathrm{N}$ and inorganic- $\mathrm{N}$ as well as total-P and soluble-P as visualized in Figure 2 and Figure 3, Table 1, Table 2, Table 3, and Table 4, respectively, we considered that the optimum ratio of the mixture of fresh manure and phosphate rock was $80: 20$ means $80 \%$ of fresh manure and $20 \%$ phosphate rock with medium grain size $(<3 \mathrm{~mm})$. To achieve the optimum quality of final produced compost, the mixture materials has to be composted optimally during 6-8 weeks of incubation, under aerobic conditions of a complete mixture of batch compost technique.

Using the optimum ratio of mixture mentioned above, the prototype of formula of the alternative fertilizer of organomineral NP or as we call 
Table 5. Characterization of the prototype formula of the alternative fertilizer of organomineral NP (Organitrophos).

\begin{tabular}{lc}
\hline \multicolumn{1}{c}{ Criteria } & Value \\
\hline Mixture Ratio of fresh manure and phosphate rock (\%) & $80: 20$ \\
Grain size of phosphate rock (mm) & $<3$ \\
Length of incubation period (weeks) & $6-8$ \\
Composting technique & Complete mixture Aerobic \\
conditions & \\
Quality of finished compost after 8 weeks of incubation & 8.14 \\
- pH & 14.93 \\
- Organic-C $(\%)$ & 2.64 \\
- Organic-N $(\%)$ & 0.46 \\
- Inorganic- $-\mathrm{N}\left(\mathrm{NH}_{4}-\mathrm{N}\right.$ and $\left.\mathrm{NO}_{3}-\mathrm{N}, \%\right)$ & 4.91 \\
- Total-P $\left(\mathrm{HCl} 25 \%, \% \mathrm{P}_{2} \mathrm{O}_{5}\right)$ & 1.66 \\
- Soluble-P $\left(\mathrm{Citric}\right.$ acid 2\%, \% $\left.\mathrm{P}_{2} \mathrm{O}_{5}\right)$ & 75.07 \\
Quantity of harvested compost after 12 week incubation & \\
(percentage from initial raw materials) & \\
\hline
\end{tabular}

organonitrophos fertilizer was characterized as mentioned below (Table 5).

\section{CONCLUSIONS}

Based on the results and discussion of the recent study, it can be concluded that (a) the optimum ratio of the mixture of fresh manure and phosphate rock was $80 \%$ to $20 \%$ with the optimum of grain size of phosphate rock was $<3 \mathrm{~mm}$; (b) the mixture materials has to be composted optimally during 6-8 weeks of incubation, under aerobic conditions of a complete mixture of batch compost technique; (c) the quality of the finished compost considerably fulfilled the requirement of standard criteria of the organic fertilizer; while (d) the quantity of harvested compost recovered up to $75.07 \%$ which was a reliable quantity attained for compost mass production. The prospective formula of organomineral NP has to be applied for testing of crop responses in pot experiment as well as in field trials. The prospective formula was also recommended to be mass produced either in full manufacturing production scale as well as in home industry scale of framer group.

\section{ACKNOWLEDGEMENTS}

We thank Directorate General of Higher Education of Ministry of Education and Culture of Republic of Indonesia for financial support of this National Strategic Featured Research Grant in the fiscal year 2011. Technical support from Soil Analysis Laboratory of Polinela (State Polytechnics of Lampung) and Environmental Laboratory, Department of Agricultural Product Technology, University of Lampung were also highly acknowledeged.

\section{REFERENCES}

Alam S, S Khalil, N Ayub and M Rashid. 2002. In vitro solubilization of inorganic phosphate by phosphate solubilizing microorganisms (PSM) from maize rhizosphere. Inter J Agri Biol 4: 454-458.

Asea PEA, RMN Kucey and JWB Stewart. 1988. Inorganic phosphate solubilization by two Penicllium spcesies insolution culture and soil. Soil Biol Biochem 20: 459-464.

Cerezine PC, E Nahas and DA Banzatto. 1988. Soluble phosphate accumulation by Aspergillus niger from fluorapatite. Appl Microb Biotech 29: 501-505.

Gupta R, R Singal, R Sankar, RM Chander and RS Kumar. 1994. A modified plate essay for screening phosphate solubilizing microorganisms. J Appl Microbiol 40: 255-260.

Hidersah R and T Simarmata. 2004. Azotobacter rhizobacteria potential in improving soil health. $J$ Nature Indon 5 (2): 127-133.

Kemenko Perekonomian RI. 2009. Statistik Pupuk Subsidi Nasional, Deputi Ekonomi Kemenko Perekonomian RI, (in Indonesian).

Kumari A, KK Kapoor, BS Kundu and RK Mehta. 2008. Identification of organic acids produced during rice straw decomposition and their role in rock phosphate solubilization. Plant Soil Environ 54: 72-77.

Misra RV, RN Roy and H Hiraoka. 2003. On-farm composting methods. Land and Water Discussion Paper. Food and Agriculture Organization of the United Nations Viale delle Terme di Caracalla 00100 Rome, Italy, 37p. 
Noor A. 2008. Perbaikan sifat kimia tanah lahan kering dengan fosfat alam, bakteri pelarut fosfat dan pupuk kandang untuk meningkatkan hasil kedelai. J Trop Soils 13 (1): $49-58$ (in Indonesian).

Priyambada ID, J Widada, S Kabirun and D Widianto. 2009. Secretion of organic acids by phosphate solubilizing bacteria isolated from oxisols. $J$ Trop Soils 14 (3): 245-251.

Ilmer P and F Schiner. 1995. Solubilization of inorganic calcium phosphate: Solubilization mechanism. Soil Biol Biochem 27: 257-264.

Reyes I, L Bernier and H Antoun. 2002. Rock phosphate solubilization and colonization of maize rhizosphere by wild and genetically modified strains of Penicillium rugulosum. Microb Ecol 44: 39-48.

Rodriguez H and R Fraga. 1999. Phosphate solubilization bacteria and their role in plant growth promotion. Biotechnol Adv 17: 319-339.
Sabarudddin, Marsi and Desti. 2011. Optimum population size of indigenous P-solubilizing bacteria to correct P availability in acid soils. J Trop Soils 16 (1): 55-62.

Siddique MT and JS Robinson. 2003. Phosphorus sorption and availability in soils amended with animal manures and sewage sludge. J Environ Qual 32: 1114-1121.

Soelaeman Y. 2008. Efektivitas pupuk kandang dalam meningkatkan ketersediaan fosfat, pertumbuhan dan hasil padi dan jagung pada lahan kering masam. $J$ Trop Soils 13 (1): $41-47$ (in Indonesian).

Traina SJ, G Sposito, D Hesterberg and U Kafkafi. 1986. Effects of $\mathrm{pH}$ and organic acids on orthophosphate solubility in an acidic, montmorilonitic soil. Soil Sci Am J 50: 45-52.

Taiwo LH and M Ogundiya. 2008. Microbial solubilization of Ogun rock phosphate in the laboratory and in soil. African J Microbiol Res 2: 308-312. 